Arq. Bras. Med. Vet. Zootec., v.69, n.1, p.89-94, 2017

\title{
Reinforcement of the pelvic diaphragm using a purse-string suture in dogs: description of technique
}

\author{
[Reforço do diafragma pélvico por meio de sutura em bolsa de fumo: descrição de técnica] \\ P.C. Moraes ${ }^{1}$, A.C. Facin ${ }^{2}$, N.M. Rosa-Ballaben ${ }^{3}$, N.M. Zanetti ${ }^{4}$, L.G.G.G. Dias ${ }^{1}$ \\ ${ }^{1}$ FCAV-UNESP - Jaboticabal, SP \\ ${ }^{2}$ Aluno de pós-graduação - UNESP-FCAV - Jaboticabal, SP \\ ${ }^{3}$ Aluno de graduação - UNESP-FCAV - Jaboticabal, SP \\ ${ }^{4}$ Médico veterinário autônomo - Ribeirão Preto, SP
}

\begin{abstract}
Recurrence of perineal hernias is frequent, and is associated to poor identification of anatomical structures during surgery, inadequate suture placement, and failure of physical support of the pelvic diaphragm after surgical reconstruction. The objective of this work is to describe a novel surgical technique for reinforcement of the pelvic diaphragm after performing the internal obturator transposition technique in dogs with perineal hernia.
\end{abstract}

Keywords: dog, hernia, herniorrhaphy, recurrence

\section{RESUMO}

As recidivas das hérnias perineais são frequentes e associadas à falha no isolamento das estruturas anatômicas, inadequada colocação de suturas e falência na sustentação do diafragma pélvico reconstruído cirurgicamente. Objetiva-se descrever uma nova técnica cirúrgica para reforço do diafragma pélvico após a realização da técnica de elevação do músculo obturador interno em cães com hérnia perineal.

Palavras-chave: cão, hérnia, herniorrafia, recidivas

\section{INTRODUCTION}

Perineal hernia results from an alteration of the pelvic diaphragm, from weakening and separation of the perineum muscles and fasciae (Ferreira and Delgado, 2003; Costa Neto et al., 2006). The pelvic diaphragm is composed of the levator ani muscle, coccygeus muscles, superficial gluteal muscle, internal obturator muscle, external anal sphincter muscle, and sacrotuberous ligament (Bellenger and Canfield, 2003). The exact cause of muscle weakening is still unknown; however, some factors such as neurogenic or senile atrophy, myopathies, prostatic hyperplasia, hormonal imbalances, and chronic constipation have been described (Hedlund, 2002; Bellenger and Canfield, 2003; Ribeiro, 2010). Perineal hernias affect mainly male dogs older than five years of age (Hedlund, 2002).

Diagnosis of this condition is based on a patient's history, clinical signs, physical examination, and radiography findings (Zerwes et al., 2011). Palpation is extremely important during physical examination in order to classify degree of atrophy, to determine integrity of the pelvic diaphragm muscles, to locate and estimate the size of the prostate (Ferreira and Delgado, 2003), as well as to identify possible concomitant rectal diseases (Moraes et al., 2013).

Classical herniorrhaphy using the anatomic reapposition technique does not reproduce the original plane of the injured muscles, and forms only a perpendicular muscular plane, which

Recebido em 7 de junho de 2016

Aceito em 13 de setembro de 2016

E-mail: pcastromoraes@yahoo.com.br 
results in rupture of the repaired pelvic diaphragm in a high percentage of cases (Argüelles et al., 2004). Therefore, some alternative surgical techniques can be employed to overcome this problem. The internal obturator muscle transposition, alone or combined with another technique, is the best surgical option (Zoran, 2005). Other techniques include semitendinosus muscle transposition for perineal reconstruction (Bellenger and Canfield, 2003; Bongartz et al., 2005), and superficial gluteal muscle transposition, its major advantage over the standard closure is to provide additional support when the coccygeal muscle is deficient (Bellenger and Canfield, 2003). In this report, we describe a technique that provides reinforcement of the repaired pelvic diaphragm, reducing the chances of recurrence.

Additionally, several other techniques have been described, such as the use of autogenous fascia lata graft (Bongartz et al., 2005), laparotomy for resolution of bilateral or complicated perineal hernia (Brissot et al., 2004), use of porcine intestinal submucosa as a biomaterial for perineal herniorrhaphy (Stoll et al., 2002), use of autologous tunica vaginalis communis in intact male dogs (Pratummintra et al., 2013), and use of natural latex biomembrane for perineal herniorrhaphy (Paulo et al., 2005).

The objective of this study is to describe a technique routinely used at the Veterinary Hospital "Governador Laudo Natel", at São Paulo State University - UNESP at Jaboticabal, SP, Brazil. This technique consists of reinforcing the pelvic diaphragm after performing the conventional technique of internal obturator muscle transposition described by Radlinsky (2013). Since this approach has yielded positive results, we considered it important to make it available to veterinary surgeons.

Under general anesthesia, ambulatory procedures are performed in a surgical preparation room to minimize contamination of the operating room. The bladder was catheterized using a urinary catheter to remove the urine, which reduces abdominal or even hernial volume, since in some cases the bladder is part of the hernia content. Additionally, the catheter will improve anatomical identification of the urethra during surgery. Next, the rectum is evacuated by manual extraction and a cylindrical device made with surgical gauzes is introduced in the ampulla recti. This device is used to facilitate identification of the rectum during surgery and to absorb fluids, minimizing soilage of the surgical field. Subsequently, the anus is obliterated using a purse-string suture.

It is important to highlight that orchiectomy and colopexy are always performed before the hernia's repair. When the bladder is in retroflexion, a deferentopexy is also performed after its repositioning (D'Assis et al., 2010). Then, the patient is then taken to the operating room and positioned in sternal recumbence with the surgical table inclined so that the perineal area remains elevated, which facilitates hernia reduction and surgical procedure. The tail is elevated and fixed using thin cords. Routine aseptic preparation of the operative site is performed; field drapes are placed leaving only the area with increased volume lateral to the anus in the fenestration.

Next, a skin incision is made on the affected area, parallel to the anus and extending dorsoventrally to the ischial tuberosity. After dissection of the subcutaneous tissue and hernial sac, hernial contents are reduced and maintained by placement of surgical sponges fixed to Kocher forceps, into the hernia ring. The internal obturator transposition technique is then performed as described by Radlinsky (2013).

After the internal obturator muscle technique and identification of all the other muscles that are part of the pelvic diaphragm, the sacrotuberous ligament is digitally located. Sutures can be made using nylon, braided polyester, or polyglactin 910. The two last have more advantages since they induce a stronger tissue reaction, which results in a more rigid support for the herniorrhaphy. The technique starts by inserting the needle with the chosen suture material through the sacrotuberous ligament, or immediately cranial to it, so that the possibility of injury to the caudal gluteal vein and artery is decreased, and to avoid adding any soft tissue between the suture material and the ligament, which could crush the tissues and traction the sciatic nerve in block, resulting in neuropraxis of the ipsilateral pelvic limb after surgery.

Next, the internal obturator muscle already transposed and the remaining pelvic diaphragm 
muscles are included in the suture so that when running the suture material through the muscles, the suture pattern will be similar to a purse-string suture. The knot is not tied at this time, and the suture material and needle remain attached to a hemostatic forceps. Depending on each case, two or three other suture pattern type purse string can be passed through the structures in the same manner as described above; however, in distinct regions, increasing the chance of better occlusion of the defect.

After the inclusion of three or four suture pattern type purse string, they are tied sequentially while observing the occlusion of structures. Note that the Kocher forceps and sponges used to reduce herniated structures are removed before tying the first knot. Next, subcutaneous tissue and skin are sutured routinely. The technique described is illustrated in detail in Figure 1.

Postoperative care includes administration of nonsteroidal anti-inflammatory drugs, analgesics, and prophylactic antibiotic therapy. The patient should wear an Elizabethan collar and have restricted activity for at least 10 days. The owner should be advised regarding reintroduction of food, and surgical wound care.

A wet diet should be administered to the patient during the first three days after surgery. Ideally, this type of diet should continue to be administered for at least 30 days, possibly for the rest of the patient's life. The surgical wound should be cleaned daily and treated with an antiseptic solution every time the animal defecates. The use of stool softeners such as Psyllium fiber or lactulose can be prescribed to avoid patient discomfort during defecation. Skin suture can be removed 10 days after the procedure.

\section{RESULTS}

We did not observe cases of recurrence after the use of purse-string suture for reinforcement of the pelvic diaphragm in the surgical routine of the Veterinary Hospital "Governador Laudo Natel". As a result, the remission of clinical signs is expected, mainly of tenesmus caused by the presence of perineal hernia, which is the main cause of recurrence. Therefore, it is important to perform both the colopexy and the herniorraphy together, especially in dogs that were diagnosed with rectal diseases.
Hormonal factors can also be the cause of tenesmus, which may involve testicular neoplasia or prostate growth induced by hormones. In addition, a weakening of the pelvic diaphragm muscles can be caused by the same factors. In this context, we emphasize the importance of orchiectomy combined with the herniorraphy and colopexy, minimizing the occurrence of postoperative tenesmus and the chances of recurrence of perineal hernia.

\section{DISCUSSION}

Recurrences of perineal hernias are frequent in small animal surgery practice, and are associated to failure during isolation of anatomical structures, inadequate suture placement, use of inappropriate suture material, and excessive tension or suture dehiscence (Mortari and Rahal, 2005). Support failure of the surgically created pelvic diaphragm due to weakening of the muscles is also mentioned as one of the causes. Recurrence rates are $10 \%$ to $48 \%$ after traditional herniorrhaphy technique and $0 \%$ to $36 \%$ after internal obturator transposition (Bellenger and Canfield, 2003). Therefore, performing an adequate herniorrhaphy technique, which results in the best possible pelvic diaphragm reinforcement, is of sum importance considering perineal hernias have high postoperative complications and recurrence rates.

In majority of cases, the simple apposition of the muscles is made difficult due to atrophy of perineal diaphragm and may predispose to recurrence (Szabo et al., 2007). The sacrotuberous ligament is often incorporated as necessary to close ventral and lateral part of the hernial deficit (Yoon and Jeong, 2010; Radlinsky, 2013). Sciatic nerve runs dorsolateral to the sacrotuberous ligament, exiting the pelvis towards the thigh and paralysis or sciatic nerve neuropraxia are often reported as a postoperative complication when sacrotuberous ligament is incorporated in the suture bite (Forterre et al., 2007). Khatri-Chhetri et al. (2016) described the spatial relationship of sciatic nerve along the sacrotuberous ligament, which gives the surgeon invaluable information to avoid sciatic entrapment and the associated complications during surgical repair of a perineal hernia. 


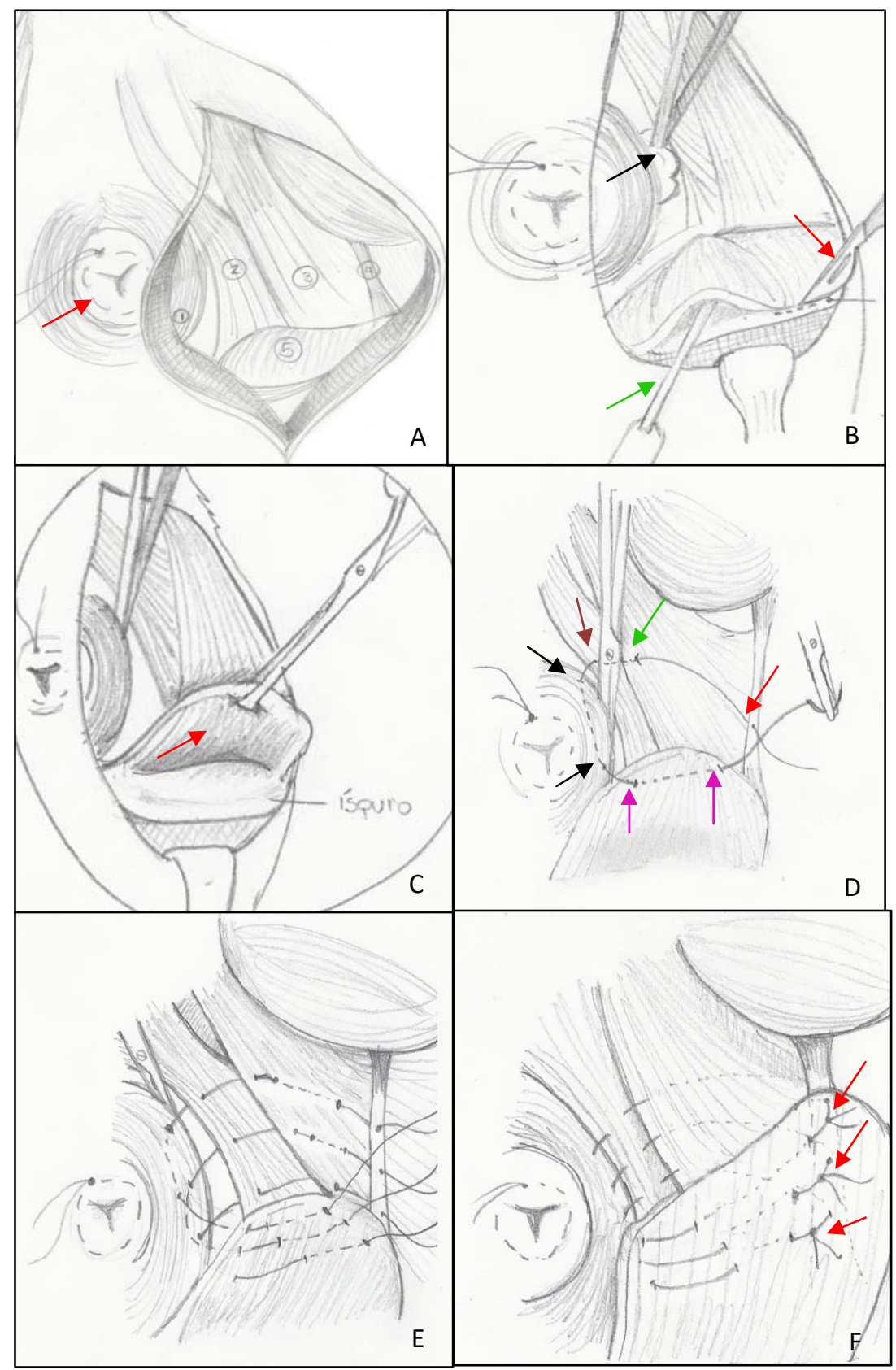

Figure 1. Schematic drawing of the anatomy of the canine right perineal region and details of the Reinforcement of the pelvic diaphragm using a purse-string suture technique. A; Normal anatomy of the pelvic diaphragm; (1) external anal sphincter muscle, (2) levator ani muscle, (3) coccygeus muscle, (4) sacrotuberous ligament, (5) internal obturator muscle. Anus with purse-string suture (red arrow). B; Internal obturator muscle being elevated from the ischiatic table with a periosteal elevator (green arrow), after incision with a scalpel (red arrow). Note surgical sponge fixed by a hemostatic forceps reducing hernial contents (black arrow). C; Internal obturator muscle elevated (red arrow), held in place with Allis tissue forceps. D; Sequence of placement of needle and suture material through anatomical structures, sacrotuberous ligament (red arrow), next coccygeus muscle (green arrow), levator ani muscle (brown arrow), external anal sphincter muscle (black arrows), and lastly, internal obturator muscle elevated (pink arrows). E; Three suture sequences are places as described previously in Figure 1D. F; The surgical sponge is removed and the three sutures are tied (red arrows). 
The animals diagnosed with perineal hernia and subjected to the herniorrhaphy technique described here did not exhibit recurrences, since besides surgery, the causes of tenesmus and dyschezia were corrected. It is important to highlight that rectal dilations and diverticula are important causes of straining and contribute to the process of perineal hernia recurrences (Mortari and Rahal, 2005). In these cases, the technique for correction of rectal sacculation through lateral resection should also be performed, as described by Moraes et al. (2013).

The traditional herniorrhaphy, by anatomic reapposition, does not reproduce the original plane of the injured muscles. It only forms a perpendicular muscle plan, which allows rupture of the repaired pelvic diaphragm in a high percentage of cases (Argüelles et al., 2004). Thus, the internal obturator muscle transposition technique, which forms a more anatomical herniorrhaphy, with less suture tension, is the best surgical choice (Zoran, 2005). However, recurrences can still occur with transposition of the internal obturator muscle owing to poor technique or muscle inability to perfectly close the dorsal portion of the hernia (Argüelles et al., 2004). The use of the internal obturator muscle transposition technique combined with other techniques (Zoran, 2005; Ronald, 2006) is thought to be related to fewer postoperative complications and recurrence rates (Ronald, 2006).

Zerwes et al. (2011) observed that the need to apply reinforcement after performing the internal obturator muscle transposition technique is a constant concern in studies involving perineal hernia. As a way to reduce the number of recurrences of perineal hernias, these authors suggest a reinforcement approach using equine pericardium membrane. The technique described in this work involves a simpler approach with the objective of promoting the strongest possible reinforcement of the pelvic diaphragm created. At the same time, it contributes to minimize the percentage of recurrences, and yields a higher surgical management success. Furthermore, the anatomical structures involved in the purse-string suture usually remain integer and can be used in the procedure described here, independent of the technique used to correct the defect.

\section{CONCLUSION}

The technique described here is effective for reinforcing the pelvic diaphragm, which reduces the rate of recurrences. Easy technical execution makes this technique a great choice for the treatment of perineal hernias, and promotes lower complication rates with stronger reinforcement of the pelvic diaphragm created.

\section{REFERENCES}

ARGÜELLES, J.C.; ISHIMI, C.; BAQUEDANO, M. Hernia perineal en el perro. Combinación de tres técnicas para la correction quirúrgica. Tres casos clínicos. Clín. Vet. Pequi. Anim., v.24, p.161-166, 2004.

BELlENGER, C.R.; CANFIELD, R.B. Perineal hernia. In: SLATTER D. (Ed.). Textbook of small animal surgery. 3.ed. Philadelphia: Saunders, 2003. p.487-498.

BONGARTZ, A.; CAROFIGLIO, F.; BALLIGAND, M. et al. Use of autogenous fascia lata graft for perineal herniorrhaphy in dogs. Vet. Surg., v.34, p.405-413, 2005.

BRISSOT, H.N.; DUPRÉ, G.P.; BOUVY B.M. Use of laparotomy in a staged approach for resolution of bilateral or complicated perineal hernia in 41 dogs. Vet. Surg., v.33, p.412-421, 2004.

COSTA NETO, J.M.; MENEZES, V.P.; TORÍBIO, J.M.M.L. et al. Tratamento cirúrgico de hérnia perineal em cão com saculação retal coexistente. Rev. Bras. Saúde Prod. Anim., v.7, p.7-19, 2006.

D'ASSIS, M.J.M.H.; COSTA NETO, J.; ESTRELA-LIMA, A.D.S. et al. Colopexia e deferentopexia associadas à omentopexia no tratamento da hérnia perineal em cães: um estudo de trinta casos. Ciênc. Rural, v.40, p.371-377, 2010 .

FERREIRA, F.; DELGADO E. Hérnias perineais nos pequenos animais. Rev. Port. Ciênc. Vet., v.545, p.3-9, 2003.

FORTERRE, F.; TOMEK, A.; RYTZ, U. et al. Iatrogenic sciatic nerve injury in eighteen dogs and nine cats (1997-2006). Vet. Surg., v.36, p.464-471, 2007. 
HEDLUND, C.S. Perineal hernia. In: FOSSUM T.W. Small animal surgery. 2.ed. St. Louis: Mosby, 2002. p.433-437.

KHATRI-CHHETRI，N.; KHATRI-CHHETRI, R.; CHUNG, C.S. et al. The spatial relationship and surface projection of canine sciatic nerve and sacrotuberous ligament: a perineal hernia repair perspective. PloS one, v.11, n.3, 2016.

MORAES, P.C.; ZANETTI, N.M.; BURGUER, C.P. et al. Correction of rectal sacculation through lateral resection in dogs with perineal hernia - technique description. Arq. Bras. Med. Vet. Zootec., v.65, p.654-658, 2013.

MORTARI, A.C.; RAHAL, S. Hérnia Perineal em cães. Ciênc. Rural, v.35, p.1220-1228, 2005.

PAULO, N.M.; SILVA, M.A.M.; CONCEIÇÃO, M. Biomembrana de látex natural (Hevea brasiliensis) com polilisina a $0,1 \%$ para herniorrafia perineal em um cão. Acta Sci. Vet., v.33, p.79-82, 2005.

PRATUMMINTRA, K.; CHUTHATEP， S.; BANLUNARA, W.; KALPRAVIDH, M. Perineal hernia repair using autologous tunica vaginalis communis in nine intact male dogs. $J$. Vet. Med. Sci., v.75, p.337-341, 2013.

RADLINSKY, M.G. Perineal hernias. In: FOSSUM, T.W. Small animal surgery. 4.ed. St. Louis: Mosby Elsevier; 2013. p.568-573.

RIBEIRO, J.C. Hérnia perineal em cães: avaliação e resolução cirúrgica: artigo de revisão. Rev. Lusófona Ciênc. Med. Vet., v.3, p.26-35, 2010.
RONALD, M.B. Anorectal surgery. In: BIRCHARD, S.J.; SHERDING, R.G. Saunders manual of small animal practice. 3.ed. St.Louis: Saunders Elservier, 2006. p.848-850.

STOLL, M.R.; COOK, J.L., POPE, E.R. et al. The use of porcine small intestinal submucosa as a biomaterial for perineal herniorrhaphy in the dog. Vet. Surg., v.31, p.379-390, 2002.

SZABO, S.; WILKENS, B.; RADASCH, RM. Use of polypropylene mesh in addition to internal obturator transposition: a review of 59 cases (2000-2004). J. Am. Anim. Hosp. Assoc., v.43, p.136-142, 2007.

YOON, H.Y.; JEONG, S.W. Coexistence of sciatic, dorsal, and caudal perineal hernias in a dog. J. Vet. Clin., v.27, p.584-587, 2010.

ZERWES, M.B.C.; STOPIGLIA, A.J.; MATERA, J.M. et al. Avaliação do tratamento cirúrgico da hérnia perineal em cães com o reforço de membrana de pericárdio eqüino preservado em glicerina a 98\%. Braz. J. Vet. Res. Anim. Sci., v.48, p.220-227, 2011.

ZORAN, D.L. Rectoanal disease. In: ETTINGER, S.J.; FELDMAN, E.C.S. Textbook of vererinary internal medicine. 6.ed. St. Louis: W.B. Saunders, 2005. v.2, p.1408-1420. 